\title{
Dermatophagoides pteronyssinus and bioelectric properties of airway epithelium: role of cysteine proteases
}

\author{
N. Roche*, T.C. Chinet*, N-E. Belouchi*, C. Julié", G.J. Huchon*
}

Dermatophagoides pteronyssinus and bioelectric properties of airway epithelium: role of
cysteine proteases . N. Roche, T.C. Chinet, N-E. Belouchi, C. Julié, G.J. Huchon. C)ERS Journals Ltd 2000

ABSTRACT: Several epidemiological studies suggest that exposure to house dust mite allergens plays a role in the pathogenesis of asthma. Since many of these allergens exhibit enzymatic properties, they may damage the airway epithelium.

To characterize the effects of low doses of Dermatophagoides pteronyssinus on the airway epithelium, the effect of $D$. pteronyssinus on the epithelial bioelectric properties of tracheal fragments of non-sensitized Lewis rats was studied, using Ussing-type chamber technique.

The addition of a crude $D$. pteronyssinus extract containing $20 \mu \mathrm{g} \cdot \mathrm{mL}^{-1}$ of Der $\mathrm{pI}$ allergen in the presence of $1.5 \mathrm{mM}$ dithiothreitol (DTT, an activator of cysteine proteases), induced a progressive increase in bioelectrical conductance $(+12.0 \pm 1.5 \%$, $\mathbf{n}=12, \mathbf{p}<\mathbf{0 . 0 0 5}$ ), an index of epithelial permeability, without affecting the short circuit current (which reflects active ion transports). The $D$. pteronyssinus-induced increase in epithelial conductance was related to the cysteine-protease activity of the allergen since it was not observed in the absence of DTT $(n=12)$, and was completely suppressed in the presence of $10 \mathrm{nM} \mathrm{E-64,} \mathrm{a} \mathrm{specific} \mathrm{inhibitor} \mathrm{of} \mathrm{cysteine} \mathrm{proteases}$ $(n=12)$. D. pteronyssinus-induced increase in epithelial conductance could be entirely attributed to an increase in the paracellular conductance $(+11.2 \pm 1.2 \%, n=8, p<0.01)$. There was no electrophysiological evidence of rupture in epithelial continuity, and no cell detachment was observed on microscopic examination.

In conclusion, the cysteine protease activity of crude Dermatophagoides pteronyssinus extract is able to increase the epithelial paracellular conductance of rat tracheal tissues, even at relatively low doses that do not induce cell detachment or cell death. Eur Respir J 2000; 16: 309-315.
*Laboratoire de Biologie et Pharmacologie des Epithéliums Respiratoires, and "Laboratoire d'Anatomo-pathologie, Université de Paris René Descartes, Hôpital Ambroise Paré, France.

Correspondence: G.J. Huchon, Service de Pneumologie et Réanimation, Hôpital de l'Hôtel Dieu, 1 place du Parvis, Notre Dame, F-75004 Paris, France. Fax: 33 142348448.

Keywords: Airway epithelium, asthma, cysteine-protease, Dermatophagoides pteronyssinus, house dust mites, permeability

Received: June 151999

Accepted after revision April 32000

This study was supported by grants from Assistance Publique-Hôpitaux de Paris (CRC \#930302 and 95028), Institut National de la Santé et de la Recherche Médicale (CNEP \#94CN38), Comité National de Lutte contre les Maladies Respiratoires et la Tuberculose, Laboratoires Stallergénes France, and Association pour 1'Etude de la Respiration et de l'Environnement. N. Roche was supported by grants from Institut Electricité Santé and Université de Paris René Descartes.
Occurrence of asthma is considered to depend on both genetic predisposition and exposure to environmental factors [1]. More than $90 \%$ of asthma cases are associated with an atopic status, and $60-100 \%$ of asthmatics are sensitized to house dust mites (HDM). In addition to their immunoglobulin(Ig)E-dependent effects [2-5], allergens of Dermatophagoides spp. may affect the airway mucosa through enzymatic mechanisms, since some of them are digestive enzymes of the mite with cysteine protease and serine protease activities $[6,7]$. Nine groups of allergens of the HDM Dermatophagoides pteronyssinus have been identified so far, and at least four have enzymatic properties which may enable allergens to cross the epithelial barrier and reach antigen-presenting cells $[6,7]$.

Therefore, several studies recently focused on the effects of enzymatic activities of $D$. pteronyssinus on the epithelium [8-12]. The cysteine protease activity of $D . p \mathrm{I}$ increases bovine bronchial mucosal permeability to albumin and is capable of causing cell detachment of cultured Madin-Darby canine kidney (MDCK) cells and canine tracheal epithelial cells [8]. In this study, the increase in epithelial permeability of bronchial fragments was observed at relatively high concentrations of highly purified allergen $\left(300 \mu \mathrm{g} \cdot \mathrm{mL}^{-1} \operatorname{Der} \mathrm{pI}\right)$, which may not be relevant with respect to usual exposure levels [8]. In addition, while the increased permeability to albumin was likely due to an effect on paracellular pathways, an effect on transcellular transports can not be ruled out since active transport of albumin has been described in animal airways [13]. In a subsequent study, it has been demonstrated that both the cysteine protease and serine protease fractions of $D$. pteronyssinus induce an increase in epithelial paracellular permeability to mannitol, which is related to tight junction breakdown and is associated with initiation of cell death [10]. However, in a more recent study $D$. pteronyssinus cysteine protease but not serine proteases altered tight junctions, allowing the allergen to cross the epithelial layer [12]. These two studies were performed on epithelial monolayers, in which the characteristics of epithelial cells and junctions may not entirely reflect that of the airway epithelium in vivo. In addition, the use of purified protease fractions in the studies by Herbert et al. [8] and Winton et al. [9-10] makes it difficult to determine which enzymatic activity is the most relevant, and which concentrations of inhaled allergens are required to achieve such effects in vivo. This 
point was addressed by WAN et al. [12], who described a method for calculation of relevant $D$. pteronyssinus concentrations, based on the daily amount of inhaled mite faecal pellets and the area of exposed bronchial mucosa. Finally, serine protease and metalloprotease activities of $D$. pteronyssinus have been shown to induce cell detachment in epithelial cell lines, together with a release of cytokines which was observed at allergen concentrations of $10 \mu \mathrm{g} \cdot \mathrm{mL}^{-1}$, while cell detachment occurred at 40 $\mu \mathrm{g} \cdot \mathrm{mL}^{-1}[11]$. Surprisingly, these authors did not find any evidence of such effects of the cysteine protease activity of Der $p \mathrm{I}$ [11], which represents at least half of $D$. pteronyssinus allergenic content $[6,7]$.

Considering the questions raised by the above-mentioned data, the authors wondered whether the cysteine protease activity, contained in low doses of crude allergen extracts, affects the epithelial paracellular and/or transcellular bioelectrical conductance of intact airway tissues. Since electrophysiological techniques based on Ussingtype chambers allow highly sensitive measurements of epithelial permeability and permit separate assessment of paracellular and transcellular pathways, rat tracheal fragments mounted in Ussing-type chambers were used to: 1) measure the effects of low doses of $D$. pteronyssinus extracts on airway bioelectrical conductance, an index of epithelial permeability; 2) determine whether the observed effects could be ascribed to the cysteine-protease activity of the major allergen Der $p \mathrm{I}$; and 3) assess whether the effect of $D$. pteronyssinus on airway epithelial permeability is due to an effect on the transcellular transports or on the paracellular pathway. The effect of $D$. pteronyssinus on airway morphology was also studied using light microscopy.

\section{Materials and methods}

\section{Animals}

Nonsensitized male Lewis rats, weighing 275-300g, were obtained from Charles River (Saint-Aubin-Lès-Elbeuf, France). The rats were housed in a positive pressure unit protected by high-efficiency particulase air (HEPA) filters (Iffa Credo, Saint-Germain sur L'Arbresle, France) under constant temperature and day-night lighting, and fed with standard rat diet (Ets L.Piètrement, Provins, France). The enzymatic effect of $D$. pteronyssinus allergens on airway epithelial bioelectric variables was characterized in 60 rat tracheal fragments obtained from 30 rats. Eight additional tracheas were used to determine whether $D$. pteronyssinus exerted its effect on transcellular or paracellular pathways. Animals were handled according to the Helsinki Convention for the Use and Care of Laboratory Animals.

\section{Allergens}

A crude D. pteronyssinus extract was used (Stallergènes Laboratories, Antony, France). This extract was titrated according to the concentration of Der $p \mathrm{I}$, which represents half of the total allergen content. The stock solution contains $200 \mu \mathrm{g} \cdot \mathrm{mL}^{-1}$ of Der $\mathrm{pI}$, diluted in the spent growth medium of the mite. A solution containing $20 \mu \mathrm{g} \cdot \mathrm{mL}^{-1}$ of Der $p$ I was obtained by diluting $1 \mathrm{~mL}$ of the stock solution in $9 \mathrm{~mL}$ of Krebs' Bicarbonate Ringer (KBR).

\section{Measurement of epithelial bioelectric properties}

The animals were anaesthetised by intraperitoneal injection of $80 \mathrm{mg} \cdot \mathrm{kg}^{-1}$ of sodium thiopenthal and killed by bleeding. The trachea was isolated from surrounding tissues, removed and immersed in $37^{\circ} \mathrm{C} \mathrm{KBR}$ gassed with oxygen $\left(\mathrm{O}_{2}\right)(95 \%)$ and carbon dioxide $\left(\mathrm{CO}_{2}\right)(5 \%)$. It was opened longitudinally by cutting the anterior wall, and mounted in Ussing-type chambers bathed with circulating $37^{\circ} \mathrm{C}$ KBR bubbled with $95 \% \mathrm{O}_{2}-5 \% \mathrm{CO}_{2}$. The surface of exposed tissue was $63.6 \mathrm{~mm}^{2}$.

The Ussing-type chambers were connected to a voltage clamp system (DVC1000, World Precision Instruments, Aston, UK) with one pair of voltage-sensing electrodes and one pair of current-passing electrodes; all electrodes consisted of $2.5 \%$ agar $3 \mathrm{M}$ KCL bridges. The transepithelial potential difference (PD) and the short-circuit current (Isc) were measured. The transepithelial bioelectrical conductance $(G)$ was determined by clamping the PD to $+10 \mathrm{mV}$, recording the deflection in $I_{\mathrm{sc}}$, and applying Ohm's law. To verify that Ohm's law $(\mathrm{PD}=I / G)$ could be used for the calculation of the conductance under our experimental conditions, we measured the intensity of the current required to clamp tissue voltage at $-10,-5,0,+5$, and $+10 \mathrm{mV}$ in six rat tracheal fragments.

\section{Experimental protocols}

For each experiment, the tissues were allowed to equilibrate in the chamber for $30 \mathrm{~min}$ before addition of agents (baseline period). $G$ was measured every $20 \mathrm{~s}$; Isc was monitored continuously and PD was recorded every 10 min. The experimental protocol was initiated when electrophysiological criteria of viability and stability were present, i.e. PD $\geq-0.5 \mathrm{mV}, I_{\mathrm{sc}}>0.5 \mu \mathrm{A} \cdot \mathrm{cm}^{-2}, G \leq 40 \mathrm{mS} \cdot \mathrm{cm}^{-2}$ and variation in $G<10 \%$ during the 30 -min baseline period [14]. Then agents were added to the apical solution, while the same volume of KBR (i.e. $0.1-1 \mathrm{~mL}$ ) was simultaneously added to the basolateral solution, to keep the hydrostatic pressure across the tissue constant. Measurements were continued for $30 \mathrm{~min}$ after the addition of agents.

Enzymatic effect of D. pteronyssinus allergens on airway bioelectric properties. The following agents and concentrations were added to the $10 \mathrm{~mL}$ apical solution: D. pteronyssinus solution containing 2 or $20 \mu \mathrm{g} \cdot \mathrm{mL}^{-1}$ Der $\mathrm{pI}$ plus $1.5 \mathrm{mM}$ dithiothreitol (DTT, an activator of cysteine-proteases); D. pteronyssinus solution containing $20 \mu \mathrm{g} \cdot \mathrm{mL}^{-1}$ Der $p$ I without DTT; and D. pteronyssinus solution containing $20 \mu \mathrm{g} \cdot \mathrm{mL}^{-1}$ Der $p \mathrm{I}$ plus $1.5 \mathrm{mM}$ DTT in the presence of $10 \mathrm{nM}$ L-trans-Epoxysuccinyl-leucylamido(4guanidino)butane (E-64, an inhibitor of cysteine proteases). The medium used to grow mites plus $1.5 \mathrm{mM}$ DTT was used as a control solution. The effect of each of these solutions was studied in 12 rat tracheal fragments. Since preliminary observations showed that the effect of $D$. pteronyssinus allergens on the bioelectrical conductance of the epithelium was a slow process, the effect of each 
solution was assessed by comparing the change in bioelectric variables during the 30 -min test period to the change during the 30 -min baseline period. To take baseline bioelectric characteristics into account, all data were expressed as percentages of the initial baseline value.

Calculation of transcellular and paracellular conductances. Paracellular conductance (Gpara) was determined using amiloride, as described by YONATH et al. [15]: addition of increasing concentrations of amiloride to the apical solution inhibits the apical membrane's $\mathrm{Na}^{+}$conductance, and therefore decreases $I$ sc and $G$. when $G$ is plotted against $I$ sc for each concentration of amiloride, the extrapolated $G$ for $I_{\mathrm{sc}}=0$ can be calculated, and represents $G$ para. The transcellular conductance $(G$ cell) can then be calculated from $G$ and $G$ para $(G=G$ cell $+G$ para $)[15]$. For each sample, it was ensured that conductance was stable during a 30-min control period, which was required for the subsequent study of $D$. pteronyssinus effect. Increasing concentrations of amiloride (i.e. $10^{-5}, 2.10^{-5}, 4.10^{-5}$, and $10^{-4} \mathrm{M}$ ) were added to the mucosal bath and, for each concentration, $G$ was plotted against Isc to allow calculation of $G$ para and $G$ cell. The tissue was then washed several times with amiloride-free KBR and allowed to equilibrate during $30 \mathrm{~min}$; after verification that $G$ had returned to baseline pre-amiloride value, the control solution (D. pteronyssinus growth medium+DTT) was added to the apical solution, and bioelectric variables were measured during $30 \mathrm{~min}$. Finally, the same increasing doses of amiloride were again added for calculation of $G$ para and $G$ cell. The effect of $D$. pteronyssinus solution containing 20 $\mu \mathrm{g} \cdot \mathrm{mL}^{-1}$ Der $\mathrm{pI}$ and $1.5 \mathrm{mM}$ DTT was then studied using the same method. Thus, for each sample $G$ para and $G$ cell could be calculated before and after addition of the control solution, and before and after addition of $D$. pteronyssinus and DTT.

\section{Solutions and reagents}

KBR was composed of (in $\mathrm{mM}$ ) $\mathrm{Na} 140, \mathrm{Cl} 120, \mathrm{~K} 5.2$, $\mathrm{HCO}_{3} 25, \mathrm{H}_{2} \mathrm{PO}_{4} 0.4, \mathrm{HPO}_{4} 2.4, \mathrm{Ca} 1.1, \mathrm{Mg} 1.2$, and glucose $5(\mathrm{pH} 7.3)$. E-64 stock solution $\left(2.10^{-5} \mathrm{M}\right)$ was obtained by solubilization of $3.6 \mathrm{mg}$ E- 64 in $500 \mathrm{~mL}$ deionized distilled water. DTT stock solution $(30 \mathrm{mM})$ was obtained by solubilization of $2.3 \mathrm{mg}$ DTT in $500 \mu \mathrm{L} \mathrm{KBR}$. Amiloride solutions were obtained by solubilization of the reagent in deionized distilled water (stock solution: $5.10^{-3} \mathrm{M}$ ). Agar was prepared by solubilization of $2.5 \mathrm{~g}$ agar in $100 \mathrm{~mL}$ of a $3 \mathrm{M} \mathrm{KCl}$ solution. Control mite culture medium was obtained by solubilization of $2 \mathrm{mg}$ of lyophilized medium in $20 \mathrm{~mL}$ of $4 \mathrm{~g} \cdot \mathrm{L}^{-1}$ ammonium bicarbonate at $37^{\circ} \mathrm{C}$, centrifugation of that solution at $2,000 \mathrm{rpm}$ for 15 $\min$ at $30^{\circ} \mathrm{C}$, and filtration. All solutions and reagents were obtained from Sigma-Aldrich (L'Isle D'Abeau Chesnes, France), except mite culture medium and allergens which were from Stallergaenes laboratories, Fresnes, France.

\section{Histological examination of tracheal fragments}

Immediately after completion of electrophysiological experiments, 6 tracheal fragments exposed to the $D$. pteronyssinus solution containing $20 \mu \mathrm{g} \cdot \mathrm{mL}^{-1}$ Der $p \mathrm{I}$ and $1.5 \mathrm{mM}$ DTT and six, exposed to control solution, were removed and fixed in Bouin solution. They were then embedded in paraffin, cut in $5 \mu \mathrm{M}$ sections, and stained with haematoxylin and eosin. Three sections of each fragment were examined by an independent observer, who was unaware of the agent to which the tissue had been exposed and how the bioelectric variables of the tissue had been affected. The following patterns were scored semi-quantatively (from 0-4): epithelial cell detachment, epithelial intercellular disruption, mucosal infiltration by inflammatory cells, and mucosal oedema.

\section{Statistical analysis}

All data are reported as means \pm SEM. Paired t-test was used for comparing changes in bioelectric variables during the test period to changes during the baseline period. Analysis of variance was used to compare the effects of tested solutions, the outcome variable being the difference between changes in bioelectric variables during baseline and test periods. Histological scores were compared using nonparametric frequency analysis. A value of $p<0.05$ was considered as significant.

\section{Results}

\section{Applicability of Ohm's law and baseline variables}

The relationship between the intensities required to clamp tissues at $-10,-5,0,+5$, and $+10 \mathrm{mV}$ and these voltages was linear $\left(r^{2}=0.94 ; p<0.005\right)$, which allowed us to use the Ohm's law for calculation of $G$ according to the following equation:

$$
\left.\mathrm{G}=\Delta \mathrm{I} / \Delta \mathrm{V}=\left(I 10 \mathrm{mv}-I_{\mathrm{sc}}\right) / 10-0\right)
$$

The baseline bioelectric variables of tracheal tissues are shown in table 1 . There was no difference between conditions ( $p>0.05$ for each comparison).

Enzymatic effect of D. pteronyssinus allergens on airway bioelectric properties

The addition of the $D$. pteronyssinus solution containing $20 \mu \mathrm{g} \cdot \mathrm{mL}^{-1}$ Der $p$ I with $1.5 \mathrm{mM}$ DTT induced a significant increase in $G$, as shown in fig. $1(\mathrm{p}<0.005)$. Other tested solutions (i.e. solutions containing $2 \mu \mathrm{g} \cdot \mathrm{mL}^{-1}$ Der $p \mathrm{I}+$ DTT, $20 \mu \mathrm{g} \cdot \mathrm{mL}^{-1}$ Der $p$ I without DTT, $20 \mu \mathrm{g} \cdot \mathrm{mL}^{-1}$ Der $p$ I + DTT in the presence of E-64, and control solution) had no significant effect on conductance $(p>0.05$ for each comparison). The effect of the $D$. pteronyssinus solution containing $20 \mu \mathrm{g} \cdot \mathrm{mL}^{-1}$ Der $p \mathrm{I}+1.5 \mathrm{mM}$ DTT was different from that of other solutions $(\mathrm{p}<0.001)$. There was no significant effect of any solution on PD and $I_{\text {sc }}$ (fig. 2).

Effect of D. pteronyssinus allergens on transcellular and paracellular conductances

As assessed by experiments using amiloride, the addition of the control solution had no effect while $D$. pteronyssinus solution containing $20 \mu \mathrm{g} \cdot \mathrm{mL}^{-1}$ Der $\mathrm{pI}$ with 1.5 
Table 1. - Bioelectric variables (mean \pm SEM) in test groups

\begin{tabular}{|c|c|c|c|c|}
\hline Tested solution & $\begin{array}{l}\text { Start of baseline } \\
\text { period }\end{array}$ & $\begin{array}{l}\text { End of baseline } \\
\text { period }\end{array}$ & $\begin{array}{l}\text { Start of test } \\
\text { period }\end{array}$ & $\begin{array}{l}\text { End of test } \\
\text { period }\end{array}$ \\
\hline \multicolumn{5}{|l|}{$G \mathrm{mS} \cdot \mathrm{cm}^{-2}$} \\
\hline D. pteronyssinus ${ }^{\#}+\mathrm{DTT}^{*}$ & $33.7 \pm 1.7$ & $34.8 \pm 1.9$ & $34.8 \pm 1.9$ & $35.9 \pm 1.9$ \\
\hline D. pteronyssinus $+\mathrm{DTT}^{+}$ & $22.7 \pm 2.7$ & $23.3 \pm 3.0$ & $23.1 \pm 2.9$ & $26.0 \pm 3.4 *$ \\
\hline D. pteronyssinus & $27.0 \pm 3.2$ & $27.3 \pm 3.9$ & $27.3 \pm 3.9$ & $26.8 \pm 4.7$ \\
\hline E-64 $(10 \mathrm{nM})+$ D. pteronyssinus ${ }^{\oplus}+$ DTT $^{*}$ & $30.2 \pm 2.4$ & $30.0 \pm 2.5$ & $28.3 \pm 2.5$ & $29.0 \pm 2.8$ \\
\hline Control solution (growth medium + DTT) & $28.3 \pm 1.7$ & $28.8 \pm 3.1$ & $28.7 \pm 3.3$ & $29.9 \pm 3.7$ \\
\hline \multicolumn{5}{|l|}{$I \mathrm{sc} \mu \mathrm{A} \cdot \mathrm{cm}^{-2}$} \\
\hline D. pteronyssinus ${ }^{\#}+\mathrm{DTT}^{+}$ & $37.1 \pm 3.4$ & $39.1 \pm 4.6$ & $35.9 \pm 5.2$ & $34.5 \pm 5.0$ \\
\hline D. pteronyssinus ${ }^{\sigma}+\mathrm{DTT}^{*}$ & $36.4 \pm 7.4$ & $38.5 \pm 8.3$ & $30.5 \pm 7.7$ & $34.5 \pm 7.7$ \\
\hline D. pteronyssinus & $37.8 \pm 6.7$ & $41.2 \pm 10.6$ & $43.1 \pm 10.8$ & $52.4 \pm 12.5$ \\
\hline E-64 $(10 \mathrm{nM})+$ D. pteronyssinus ${ }^{\top}+$ DTT $^{*}$ & $31.1 \pm 5.8$ & $38.8 \pm 6.4$ & $37.8 \pm 7.2$ & $43.1 \pm 7.8$ \\
\hline Control solution (growth medium + DTT ${ }^{*}$ ) & $33.8 \pm 5.4$ & $37.8 \pm 8.2$ & $35.1 \pm 7.8$ & $35.8 \pm 7.8$ \\
\hline \multicolumn{5}{|l|}{ PD (mV, negative) } \\
\hline D. pteronyssinus + DTT $^{*}$ & $1.1 \pm 0.1$ & $1.2 \pm 0.2$ & $0.7 \pm 0.2$ & $0.6 \pm 0.2$ \\
\hline D. pteronyssinus ${ }^{\oplus}+\mathrm{DTT}^{+}$ & $1.5 \pm 0.3$ & $1.6 \pm 0.3$ & $1.2 \pm 0.3$ & $1.2 \pm 0.2$ \\
\hline D. pteronyssinus & $1.5 \pm 0.3$ & $1.6 \pm 0.4$ & $1.6 \pm 0.4$ & $1.8 \pm 0.4$ \\
\hline $\mathrm{E}-64(10 \mathrm{nM})+$ D. pteronyssinus ${ }^{\top}+\mathrm{DTT}^{*}$ & $1.0 \pm 0.2$ & $1.3 \pm 0.2$ & $1.3 \pm 0.2$ & $1.6 \pm 0.3$ \\
\hline Control solution (growth medium $+1.5 \mathrm{mM} \mathrm{DTT}^{\star}$ ) & $1.3 \pm 0.2$ & $1.4 \pm 0.4$ & $1.1 \pm 0.3$ & $1.3 \pm 0.4$ \\
\hline
\end{tabular}

$\mathrm{n}=12$ for each condition. ${ }^{*}: 2 \mu \mathrm{g} \cdot \mathrm{mL}^{-1} \operatorname{Der} \mathrm{pI}$; ${ }^{\uparrow}: 20 \mu \mathrm{g} \cdot \mathrm{mL}^{-1} \operatorname{Der} P \mathrm{I} ;{ }^{*}: \mathrm{p}=0.0001$ when compared to baseline of test period. G: bioelectrical conductance; Isc: short cut impedance; PD: potential difference; D. pteronyssinus: Dermatophagoides pteronyssinus; DTT: dithiothreitol; Der PI: D. pteronyssinus allergen I; ${ }^{\#}: 2 \mu \mathrm{g} \cdot \mathrm{mL}^{-1}$ Der $\mathrm{pI} ;{ }^{\uparrow}: 20 \mu \mathrm{g} \cdot \mathrm{mL}^{-1}$ Der $\mathrm{pI}$; ${ }^{\ddagger}: 1.5 \mathrm{mM}$ DTT.

mM DTT induced an increase in $G$ and $G$ para $(\mathrm{p}<0.05$ and $\mathrm{p}<0.01$, respectively), without affecting $G$ cell (fig. 3).

\section{Histological examination of tracheal fragments}

Epithelial cell detachment, epithelial intercellular disruption, mucosal infiltration by inflammatory cells, and mucosal oedema did not differ between fragments exposed to the D. pteronyssinus solution containing $20 \mu \mathrm{g} \cdot \mathrm{mL}^{-1}$

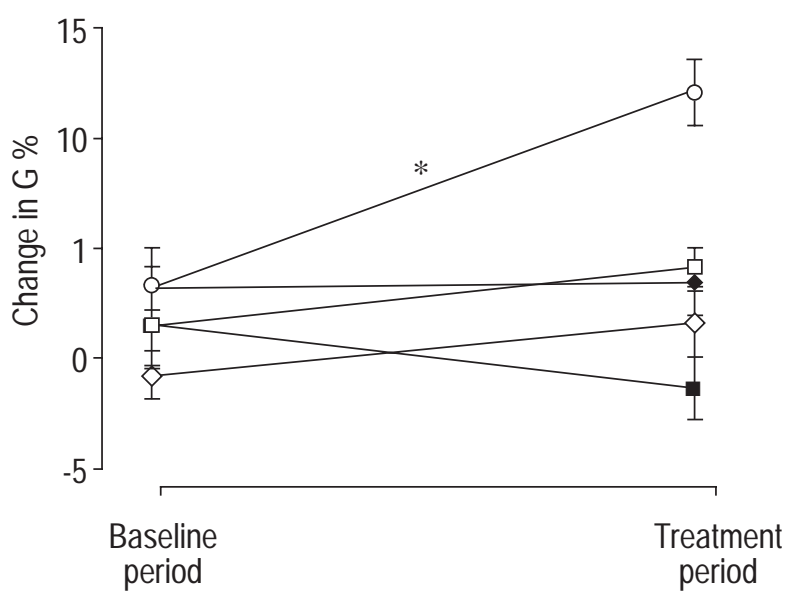

Fig. 1. - Change in conductance $G$, expressed as the percentage of the initial baseline value, during the 30 -min baseline period and the 30 -min test period. $\mathrm{n}=12$ for each condition. D. pteronyssinus: Dermatophagoides pteronyssinus; $(\mathrm{O})$ : Dermatophagoides pteronyssinus $\left(20 \mu \mathrm{g} \cdot \mathrm{mL}^{-1}\right.$ Der pI) + DTT (1.5 mM); ( $)$ : Dermatophagoides pteronyssinus $(2$ $\left.\mu \mathrm{g} \cdot \mathrm{mL}^{-1} \operatorname{Der} \mathrm{pI}\right)+\mathrm{DTT}(1.5 \mathrm{mM}) ;(\boldsymbol{)})$ : Dermatophagoides pteronyssinus $\left(20 \mu \mathrm{g} \cdot \mathrm{mL}^{-1}\right.$ Der $\left.p \mathrm{I}\right)$ without DTT; $(\diamond):$ Dermatophagoides pteronyssinus $\left(20 \mu \mathrm{g} \cdot \mathrm{mL}^{-1}\right.$ Der $\left.\mathrm{pI}\right)+\mathrm{DTT}(1.5 \mathrm{mM})$ in the present of E64 $(10 \mathrm{nM}) ;(\square)$ : control, i.e. mite growth medium + DTT $(1.5 \mathrm{mM})$. *: significant increase in $G(\mathrm{p}<0.005)$. The effect of Dermatophagoides pteronyssinus $\left(20 \mu \mathrm{g} \cdot \mathrm{mL}^{-1} \operatorname{Der} \mathrm{pI}\right)+\mathrm{DTT}(1.5 \mathrm{mM})$ was different from that of other variables $(\mathrm{p}<0.001)$.
Der $p$ I plus $1.5 \mathrm{mM}$ DTT and fragments exposed to control solution ( $\mathrm{p}>0.05$ for each comparison).

\section{Discussion}

This study shows that D. pteronyssinus allergens increase epithelial permeability, as assessed by airway conductance $(G)$. This effect is probably due to the cysteine protease enzymatic activity of the allergen, since it was observed only in the presence of DTT, an activator of cysteine proteases, and it was inhibited by E-64, an inhibitor of cysteine proteases which has no effect on $D$. pteronyssinus serine proteases $[10,16]$. D. pteronyssinusinduced increase in $G$ could be entirely attributed to an increase in the paracellular conductance. Finally, $D$. pteronyssinus allergens have no significant effect on active electrogenic ion transports, as assessed by $I$ sc. Changes in epithelial paracellular conductance were not associated with histologic evidence of epithelial injury or electrophysiological evidence of rupture in epithelial continuity. These data suggest that the cysteine protease activity of $D$. pteronyssinus affects epithelial paracellular pathways at doses lower than those required to induce cell detachment or cell death.

The magnitude of the $D$. pteronyssinus-induced increase in airway epithelial conductance was small, which prevents any conclusion as to whether it may be associated with an increase in epithelial permeability to proteins to be drawn; this small magnitude may be explained by the deliberately smaller concentrations of allergens to which the tracheal fragments are exposed, compared to those that induced cell detachment and/or increased epithelial permeability in other studies [8, 10-12]. The physiological and clinical relevance of such a small effect may be questioned. However, some sites of the airways may be exposed to much higher concentrations of allergens, since each $D$. pteronyssinus faecal pellet contains up to $0.1 \mathrm{ng} \operatorname{Der} \mathrm{pI}$ in a sphere 

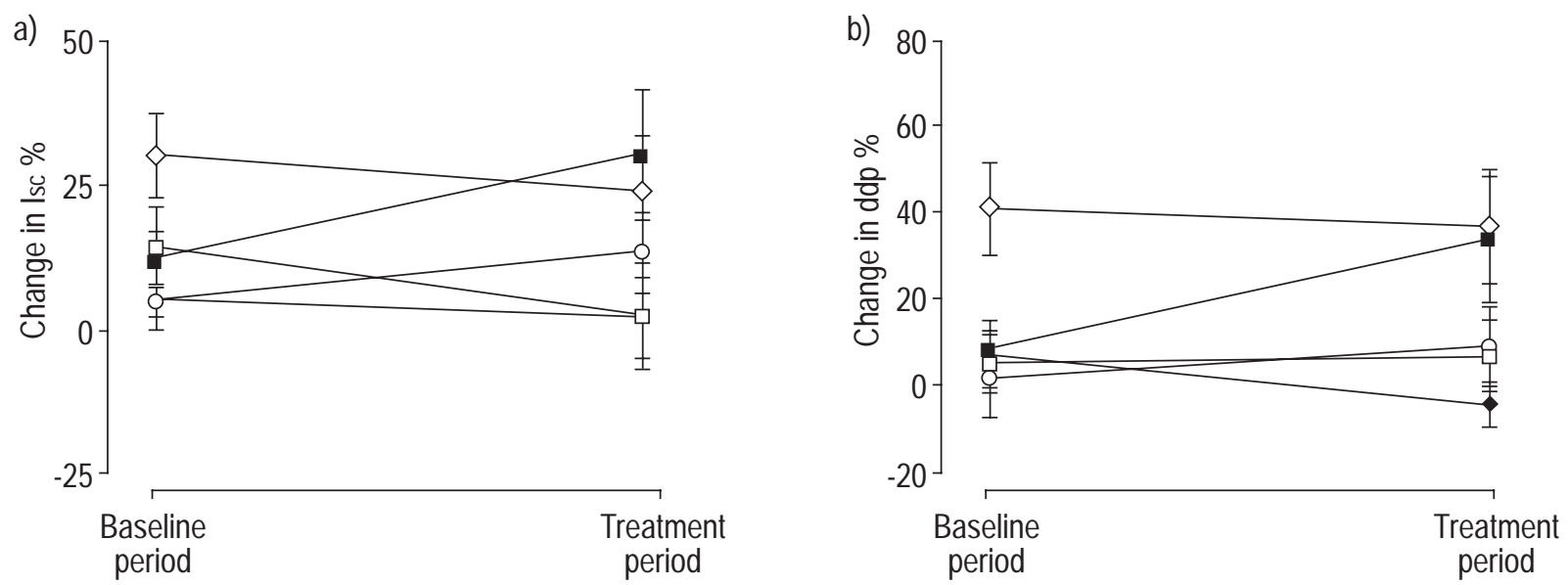

Fig. 2. - Change in a) short-circuit current ( $I_{\mathrm{sc}}$; and b) potential difference (PD)), during the 30-min baseline period and the 30-min test period. Data are expressed as \% of the initial baseline value. $\mathrm{n}=12$ for each condition. D. pteronyssinus: Dermatophagoides pteronyssinus; $(\bigcirc)$ : D. pteronyssinus $(20$ $\mu \mathrm{g} \cdot \mathrm{mL}^{-1}$ Der $\left.\mathrm{pI}\right)+\mathrm{DTT}(1.5 \mathrm{mM}) ;(\mathbf{\square}):$ D. pteronyssinus $\left(2 \mu \mathrm{g} \cdot \mathrm{mL}^{-1}\right.$ Der $\left.\mathrm{pI}\right)+\mathrm{DTT}(1.5 \mathrm{mM}) ;(\diamond):$ D. pteronyssinus $\left(20 \mu \mathrm{g} \cdot \mathrm{mL}^{-1}\right.$ Der $\left.p \mathrm{I}\right) \mathrm{without} \mathrm{DTT}$; $(\diamond)$ : D. pteronyssinus $\left(20 \mu \mathrm{g} \cdot \mathrm{mL}^{-1}\right.$ Der $\left.\mathrm{II}\right)+\mathrm{DTT}(1.5 \mathrm{mM})$ in the present of E64 $(10 \mathrm{nM}) ;(\square)$ : control, i.e. mite growth medium + DTT $(1.5 \mathrm{mM}) . *$ : tested agents induced no significant effect.

of $20 \mu \mathrm{m}$ in diameter, which corresponds to a concentration of $\sim 10 \mathrm{mg} \cdot \mathrm{mL}^{-1}$ in the pellet $[17,18]$. Moreover, experimental conditions only allowed determination of the consequences of a single, and brief, in vitro exposure. Since the increase in airway epithelial conductance after exposure to $20 \mu \mathrm{g} \cdot \mathrm{mL}^{-1}$ Der $\mathrm{pI}+\mathrm{DTT}$ was a slow process, the effect of repeated and/or prolonged exposure may be greater.

The cysteine protease-induced increase in epithelial paracellular conductance could be the consequence of: direct alteration of intercellular junctions by the cysteineprotease activity of Der $p \mathrm{I}$; or inflammatory phenomena, either induced by the cysteine protease of $D$. pteronyssinus, or that lead to the production of cysteine proteases by inflammatory cells. Such phenomena could be mediated by D. pteronyssinus-induced release of cytokines such as monocyte chemotactic protein-1 (MCP-1), granulocytemacrophage colony stimulating factor (GMCSF), interleukin (IL)-6, or IL-8, which production by epithelial cells is enhanced by house dust mite proteases [11]; other molecules such as soluble CD23 (sCD23) may also play a role, since Der $p \mathrm{I}$ induces the release of this product by cleavage of membrane-bound CD23, which in turn increases the production of IgE by B-cells [19]. Finally, other inflammatory mediators may be involved, since Der $p$ I activates the pro-inflammatory transcriptional factor $\mathrm{NF}-\kappa \mathrm{B}[20]$. However, the effect of such mediators and cytokines on airway epithelial bioelectric properties is unknown. Furthermore, a role of inflammatory cells is unlikely, since Lewis rats were not previously sensitized to D. pteronyssinus and were free of respiratory diseases, and since histologic scores of mucosal infiltration by inflammatory cells were similar in fragments exposed to D. pteronyssinus $\left(20 \mu \mathrm{g} \cdot \mathrm{mL}^{-1}\right)+\mathrm{DTT}$ and in fragments exposed to the control solution.

Thus, a direct enzymatic effect on intercellular junctions appears to be the most likely explanation for the D. pteronyssinus-induced increase in airway epithelial paracellular conductance. Tight junctions are made of proteins $[12,21-$ 23 , and are known to be damaged by exogenous enzymes such as elastase from Pseudomonas aeruginosa [24]. Cysteine protease and serine protease fractions of $D$. pteronyssinus have also been shown to damage tight junctions of epithelial cell monolayers $[10,12]$; this effect appears to be due to a cleavage of at least two tight junction proteins, occludin and claudin-1, in which some putative cleavage sites have been identified [12]. In our study, $D$. pteronyssinus serine-proteases did not appear to participate in the effect of the crude D. pteronyssinus extract on airway epithelial paracellular conductance, since this effect was observed only in the presence of DTT, an activator of cysteine proteases, and was entirely inhibited by E-64, which does not affect the activity of $D$. pteronyssinus serine proteases $[10,16]$. An additional minor effect of serine proteases can not be completely ruled out since the effect of serine protease activators and inhibitors was not studied. However, WAN et al. [12] found no effect

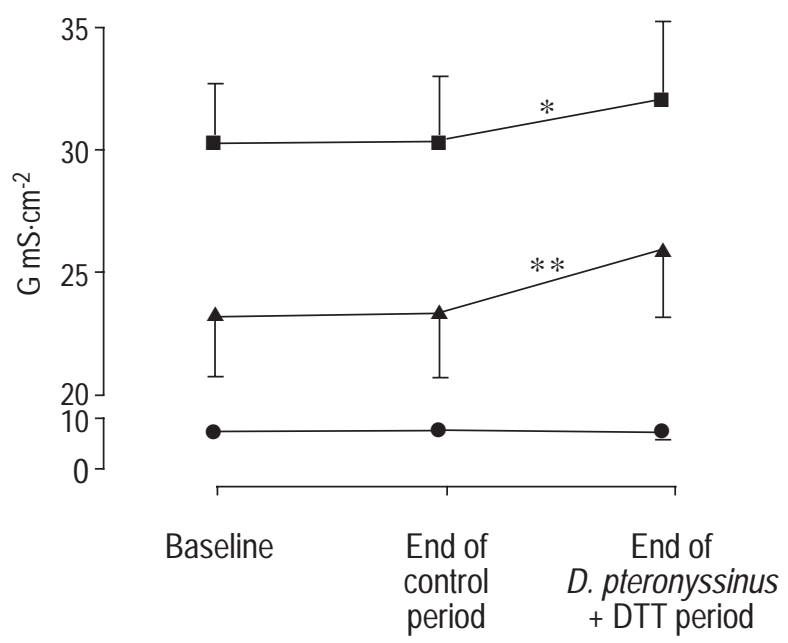

Fig. 3. - Effect of control solution (mite growth medium $+1.5 \mathrm{mM}$ DTT $)$ and D. pteronyssinus $\left(20 \mu \mathrm{g} \cdot \mathrm{mL}^{-1}\right.$ Der $\left.\mathrm{pI}\right)$ with DTT $(1.5 \mathrm{mM})$ on total $(\mathrm{G}, \mathbf{\square})$, paracellular $(G$ para, $\mathbf{\Delta})$ and transcellular (Gcell, conductances in eight tracheal fragments $* *: \mathrm{p}<0.01 ; *: \mathrm{p}<0.05$. 
of serine protease inhibitors on the effect of $D$. pteronyssinus on tight junctions in epithelial monolayers of human origin.

As in studies by HERBERT et al. [8] and TOMEe et al. [11], evidence of cell death, which would have dramatically affected the bioelectric variables in our experiments was not observed. Conversely, WinTON et al. [10] found that the increase in the paracellular conductance of epithelial cell monolayers was associated with initiation of cell death. These discrepancies may be due to a greater susceptibility of the cell lines they used to protease-induced apoptosis. An alternative explanation would be that the protease activities, which induced apoptosis of epithelial cells in their study, correspond to very high concentrations of allergens.

In the studies by Herbert et al. [8] and TOMEe et al. [11], concentrations of Der $p$ I similar to ours (i.e. $2-20 \mu \mathrm{g} \cdot \mathrm{mL}^{-1}$ ) induced a significant cell detachment only in cultured cells, while much higher concentrations (i.e. $300 \mu \mathrm{g} \cdot \mathrm{mL}^{-1}$ ) were required to increase epithelial permeability to albumin and detach epithelial cells in isolated bronchial segments; this is probably due to differences in cohesiveness between cultured epithelium and tissues, and may explain why cell detachment in tracheal tissues with Der $p$ I concentrations of $20 \mu \mathrm{g} \cdot \mathrm{mL}^{-1}$ was not observed. Therefore, comparisons between studies must be cautious since epithelial permeability and cohesiveness may be different from one species (or cell line) to another.

Herbert et al. [8] observed that Der pI induced a detachment of MDCK cells even without addition of reducing agents, which suggests that these cells (or their culture medium) were able to reduce the cysteine protease by themselves. This was not the case in the present study, which could be related to a lower thiol-reducing potential of rat tracheal cells compared with MDCK cells. Similarly, the lack of effect of the cysteine protease activity that was reported by ToMEe et al. [11] may be due to a low thiol-reducing potential of the cell lines used or its culture medium. In humans, airway secretions contain agents such as glutathione, which can activate cysteine-proteases [8].

The in vivo relevance of doses of allergen used in in vitro studies is difficult to assess. During usual domestic activity, doses of allergens, to which subjects are environmentally exposed, are very low, although they are likely to increase during close contact with reservoirs such as mattresses [17, 18]. Besides, although eighty percent of mite allergens are contained in particles which have a diameter of more than $10 \mu \mathrm{m}[17,25]$, up to $15 \%$ of such particles can deposit in the human airways [26], so that an individual may inhale $>200$ mite faecal pellets per day [12]. Considering that each faecal particle contains $\sim 10 \mathrm{mg} \cdot \mathrm{mL}^{-1}$ $\operatorname{Der} p \mathrm{I}$ [17], it may be hypothesized that very high local concentrations are reached in some limited areas of the airways when allergens elute from these particles in airway lining fluid $[12,18]$.

In conclusion, the use of electrophysiological techniques allowed to demonstrate that the cysteine protease activity of house dust mite allergens increases the paracellular epithelial permeability of airway tissues at concentrations lower than those which induce cell detachment or cell death. If such a phenomenon is relevant in vivo, the resulting increase in epithelial permeability may facilitate the penetration of allergens and toxic agents in the airway mucosa and, thereby, the contact between these agents and inflammatory cells. It may also enhance the transepithelial passage of inflammatory mediators. Thus, the enzymatic properties of $D$. pteronyssinus may play a role in the initiation and amplification of the bronchial immunological and inflammatory phenomena that are observed in asthma.

Acknowledgements. The authors wish to thank K. Fan Chung for reviewing the manuscript.

\section{References}

1. Peat JK, Gray S, Woolcock AJ. The epidemiology of asthma. Curr Opin Pulmon Med 1995; 1: 9-15.

2. Cristina Gonzalez M, Diaz P, Galleguillos FR, Ancic P, Cromwell O, Kay AB. Allergen-induced recruitment of bronchoalveolar helper (OKT4) and suppressor (OKT8) T-cells in asthma. Am Rev Respir Dis 1987; 13: 600-604.

3. Diaz P, Gonzalez MC, Galleguillos FR, et al. Leukocytes and mediators in bronchoalveolar lavage during allergeninduced late-phase asthmatic reactions. Am Rev Respir Dis 1989; 139: 1383-1389.

4. O'Brien RM, Thomas WR, Wooton AM. T-cell responses to the purified major allergens from the house dust mite Dermatophagoides pteronyssinus. J Allergy Clin Immunol 1992; 189: 1021-1031.

5. Rawle FC, Mitchell EB, Platts-Mills TAE. T cell responses to the major allergen from the house-dust mite Dermatophagoides pteronyssinus, antigen P1 comparison of patients with asthma, atopic dermatitis, and perennial rhinitis. Immunol 1984; 133: 195-201.

6. Stewart GA. Dust mite allergens. Clin Rev Allergy Immunol 1995; 113: 135-150.

7. King CM, Simpson RJ, Moritz RL, Reed GE, Thompson PJ, Stewart GA. The isolation and characterization of a novel collagenolytic serine protease allergen (Der $p$ 9) from the dust mite dermatophagoides pteronyssinus. $J$ Allergy Clin Immunol 1996; 198: 739-747.

8. Herbert CA, King CM, Ring PC, et al. Augmentation of permeability in the bronchial epithelium by the house dust mite allergen Der pI. Am J Respir Crit Care Med 1995; 12: 369-378.

9. Winton HL, Wan H, Cannell MB, et al. Cell lines of pulmonary and nonpulmonary origin as tools to study the effects of house dust mite proteinases on the regulation of epithelial permeability. Clin Exp Allergy 1998; 28: $1273-$ 1285.

10. Winton HL, Wan H, Cannell MB, et al. Class specific inhibition of house dust mite proteinases which cleave cell adhesion, induce cell death and which increase the permeability of lung epithelium. Br J Pharmacol 1998; 124: $1048-1059$.

11. Tomee JF, van Weissenbruch R, de Monchy JG, Kauffman HF. Interactions between inhalant allergen extracts and airway epithelia cells: effect on cytokine production and cell detachment. J Allergy Clin Immunol 1998; 102: $75-85$.

12. Wan H, Winton HL, Soeller C, et al. Der $p$ I facilitates transepithelial allergen delivery by disruption of tight junctions. J Clin Invest 1999; 104: 123-133.

13. Johnson LG, Cheng PW, Boucher RC. Albumin absorption by canine bronchial epithelium. J Appl Physiol 1989; 66: 2772-2777. 
14. Sestini P, Bienenstock J, Crowe SE, et al. Ion transport in rat tracheal epithelium in vitro. Role of capsaicin-sensitive nerves in allergic reactions. Am Rev Respir Dis 1990; 1141: 393-397.

15. Yonath J, Civan MM. Determination of the driving force of the Na pump in toad bladder by means of vasopressin. J Membrane Biol 1971; 5: 366-385.

16. Stewart GA, Lake FR, Thompson PJ. Faecally derived hydrolytic enzymes from Dermatophagoides pteronnyssinus. Physicochemical characterisation of potential allergens. Int Arch Allergy Appl Immunol 1991; 195: 248-256.

17. Tovey ER, Chapman MD, Wells CM, Platts-Mills TAE. The distribution of dust mite allergen in the houses of patients with asthma. Am RevRespirDis 1981;1124:630-635.

18. Sporik R, Chapman MD, Platts-Mills TAE. House dust mite exposure as a cause of asthma. Clin Exp Allergy 1992; 22: 897-906.

19. Hewitt CRA, Brown AP, Hart BJ, Pritchard DI. A major house dust mite allergen disrupts the immunoglobulin $\mathrm{E}$ network by selectively cleaving CD23: innate protection by antiproteases. $J$ Exp Med 1995; 182: 1537-1544.

20. Stacey MA, Sun G, Vassaili G, Marini M, Bellini A, Mattoli S. The allergen Der $p$ I induces NF-кB activation through interference with IкB alpha function in asthmatic bronchial epithelial cells. Biochem Biophys Res Commun 1997; 1236: 522-526.

21. Griepp EB, Dolan WL, Robbins ES, Sabatini DD. Participation of plasma membrane proteins in the formation of tight junctions by cultured epithelial cells. $J$ Cell Biol 1983; 96: 693-702.

22. Gumbiner B, Simons K. A functional assay for proteins involved in establishing an epithelial occluding barrier: identification of a Uvomorulin-like polypeptide. J Cell Biol 1986; 102: 457-468.

23. Gumbiner B. Structure, biochemistry, and assembly of epithelial tight junctions. Am J Physiol (Cell Physiol) 1987; 253: C749-C758.

24. Azghani AO. Pseudomonas aeruginosa and epithelial permeability role of virulence factors elastase and exotoxin A. Am J Respir Cell M Biol 1996; 115: 132-140.

25. Platts-Mills TAE, Heymann PW, Longbottom JL, Wilkins SR. Airborne allergens associated with asthma: particle sizes carrying dust mite and rat allergens measured with a cascade impactor. J Allergy Clin Immunol 1986; 77: 850857.

26. Svartengren M, Falk R, Linnman L, Philipson K, Camner P. Deposition of large particles in human lung. Exp Lung Res 1987; 12: 75-88. 